\title{
The Importance of Take-Out Food Packaging Attributes: Conjoint Analysis and Quality Function Deployment Approach
}

\author{
Dyah Lestari Widaningrum ${ }^{1}$ \\ ${ }^{1}$ Industrial Engineering Department, Faculty of Engineering, Bina Nusantara University, Jl. KH Syahdan 9, Jakarta, \\ 11480, Indonesia, dwidaningrum@binus.edu
}

\begin{abstract}
This research aims to investigate the importance of take-out food packaging attributes, using conjoint analysis and QFD approach among consumers of take-out food products in Jakarta, Indonesia. The conjoint results indicate that perception about packaging material (such as paper, plastic, and polystyrene foam) plays the most important role overall in consumer perception. The clustering results that there is strong segmentation in which take-out food packaging material consumer consider most important. Some consumers are mostly oriented toward the colour of packaging, while another segment of customers concerns on packaging shape and packaging information. Segmentation variables based on packaging response can provide very useful information to maximize image of products through the package's impact. The results of House of Quality development described that Conjoint Analysis - QFD is a useful combination of the two methodologies in product development, market segmentation, and the trade off between customers' requirements in the early stages of HOQ process
\end{abstract}

\section{Introduction}

Today, fast food industry is growing in Indonesia especially in Jakarta as urban area. One of the services provided by the fast food restaurant is call take-out food service. This service includes direct purchase at restaurant (or special kiosk provided by restaurant) as well as ordering by phone/fax/internet.

While such convenience seems irresistible to consumers, widespread purchase of take-out food brings about concerns of several problematic factors: the amount of time from purchase to consumption, the type of container, and the consumer knowledge as to reheating food product safely (Boyce et al., 2008). Packaging used by fast food restaurants hold foods that frequently consume outside the restaurant

Silayoi and Speece (2005) demonstrate that the conjoint study seems to have been an effective way to examine how consumers view packaging, and Surjandari (2010) describes that Conjoint Analysis - QFD is a useful combination of the two methodologies in product development, market segmentation, and the trade off between customers' requirements in the early stages of the HOQ process. This research examines consumer response packaging using a Conjoint Analysis and Quality Function Deployment (QFD) among consumers for take-out food products in Jakarta, Indonesia. The relationship between consumer choices in various market segments and design characteristics of packaging is a key issue that marketers of packaged food products must understand to develop effective marketing strategy (Silayoi and Speece, 2005).

\subsection{Research Problem}

- What is take-out food packaging attributes based on consumers perception?

- How is the consumer segmentation based on their preferences?

- How is the conjoint analysis results can use for packaging development?

\subsection{Objectives of the Study}

- To identify take-out food packaging attributes based on consumers perception

- To define consumer segmentation based on their preferences

- To develop the House of Quality in the early stage using the conjoint analysis results

\section{Methodology}

This study consists of 5 steps as can be seen in Figure 1 . Conjoint Analysis and Cluster Analysis in Step 1 to 3 use empirical data obtained from the survey on consumer of take-out food product. This survey consists of several 
activities as can be seen in Figure 2. The results of these steps used as information to mediate between consumer expectation and product designer. This study have prioritized technical requirements for all customer segments, by developing House of Quality, that consists of several activities as can be seen in Figure 3.

Figure 1. Research Methodology: Conjoint-QFD (source: Surjandari, 2010)

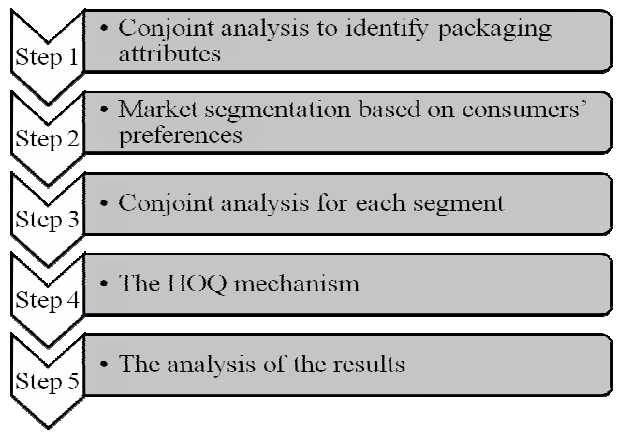

Figure 2. Conjoint Analysis Methodology (source: Hair et al, 2006)

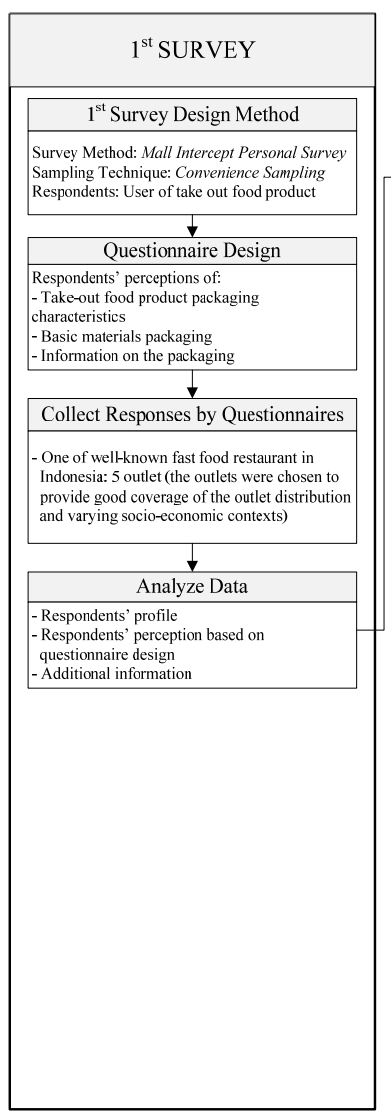

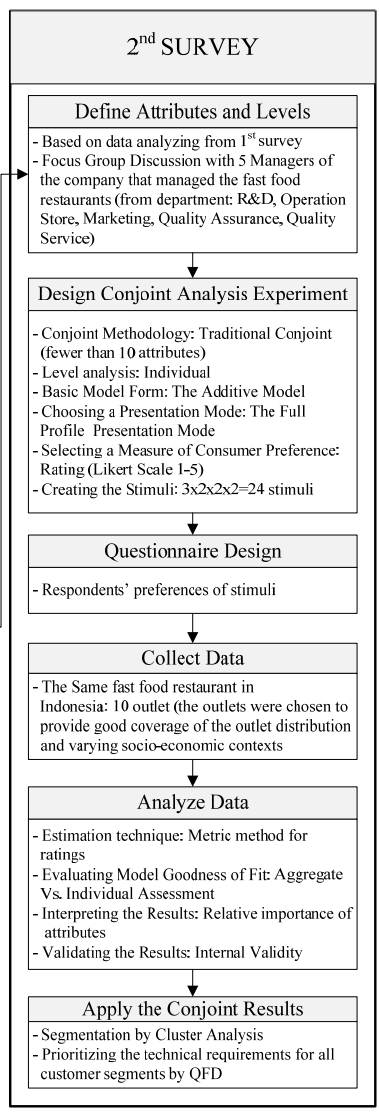

\section{Collecting Data}

The object of this study is the user consumers of take-out food products, from one of well-known fast food restaurant in Indonesia. This restaurant has had 62 outlets in Jakarta and 85 outlet in others area (Banten, West Java, Central Java, East Java, Jogjakarta and Bali), but the research focus on Jakarta Area, to fulfil the convenience life style. Packaging that analyzed in this study is packaging that used to contain the packaged menu, consists of rice, main menu/product, side dishes, salad, and sauce.

Figure 3. Develop House of Quality (source: Surjandari, 2010)

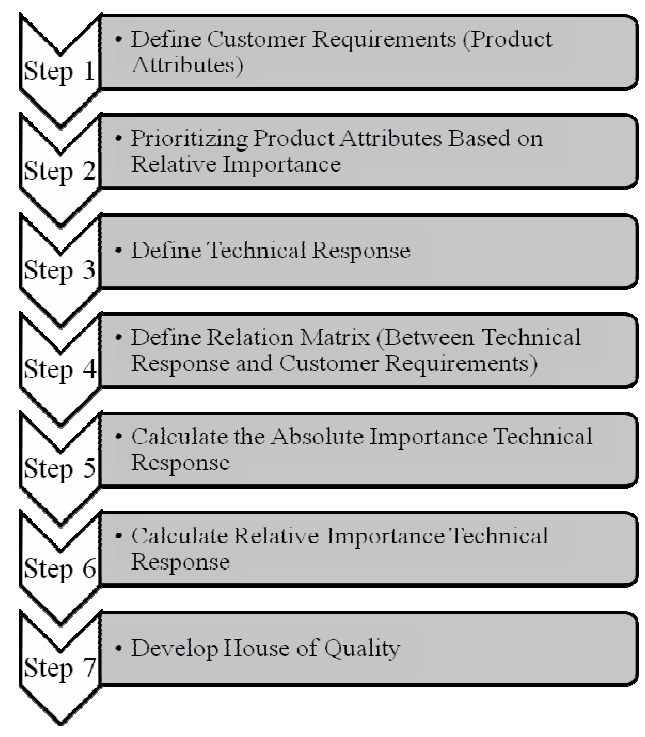

\section{Analyzing Data}

\subsection{Step 1: Conjoint Analysis}

Attributes and levels of take-out food packaging are defined based on data analyzing from $1^{\text {st }}$ survey and Focus Group Discussion from various department within the company, as can be seen in Table 1.

Table 1. Attributes and Levels of Take-Out Food Packaging

\begin{tabular}{|c|c|c|c|}
\hline & Attributes & & Levels \\
\hline \multirow{3}{*}{1} & \multirow{3}{*}{ Packaging Material } & 1 & Plastic \\
\hline & & 2 & Paper \\
\hline & & 3 & Polystyrene Foam \\
\hline \multirow{2}{*}{2} & \multirow{2}{*}{$\begin{array}{l}\text { Information on the } \\
\text { Packaging }\end{array}$} & 1 & Detail Information*) \\
\hline & & 2 & Non Detail Information \\
\hline \multirow{2}{*}{3} & \multirow{2}{*}{ Container Shape } & 1 & With Compartment \\
\hline & & 2 & Without Compartment \\
\hline \multirow{2}{*}{4} & \multirow{2}{*}{ Container Colour } & 1 & Light (White, Beige, etc) \\
\hline & & 2 & Dark (Black, Brown, etc) \\
\hline
\end{tabular}

*) information consists brand name, brand logo, name of product, food grade symbol, recycling code.

The design stimuli in this study using SPSS 15.0 software and so was the conjoint data analyzing. Data collected from the respondent preference $2^{\text {nd }}$ survey was 
total of 287 data, but only 274 data used for the analysis. Thirteen data were unusable for data analysis because the participants failed to complete all portions of the surveys or not eligible respondents.

Pilot test of 30 respondents conducted to ensure that there is clarity of statement on the questionnaire, and the result indicates that the survey instrument is reliable.

Goodness of Fit conducted to ensure the accuracy and consistency of the respondents in filling out the questionnaire, with the minimum coefficient of Pearson's $\mathrm{R}$ for individuals is 0.4 with $\mathrm{p}$-value $<0.05$. Pearson's coefficient $\mathrm{R} \geq 0.4$ indicates the strength of correlation between the results predicted ranking with actual ranking of data is moderate to very strong. P-value $<0.05$ indicates a significant correlation between the results predicted ranking with the actual ranking of data, and it can be concluded that the model was accurate so that the calculation of data worth for further analysis.

Of the 274 data used, there were 11 data are not worthy to be further processed, because it has pvalue $>0.05$ or Pearson's $R$ value $<0.4$. Of 263 data were analyzed, individually generated utility value of each level with standard error of the utility, as well as the utilities importance value of each attribute take-out food product packaging, as can be seen in Table 2 .

Table 2. Conjoint Analysis Result $(\mathrm{n}=263)$

\begin{tabular}{|c|c|c|c|c|}
\hline Attribute & Level & $\begin{array}{l}\text { Utility } \\
\text { Estimate }\end{array}$ & $\begin{array}{l}\text { Std. } \\
\text { Err. }\end{array}$ & $\begin{array}{c}\text { Importance } \\
\text { Values }\end{array}$ \\
\hline \multirow{3}{*}{ 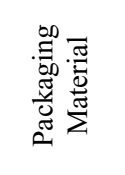 } & Plastic & -.046 & .023 & \multirow{3}{*}{44.539} \\
\hline & Paper & .210 & .023 & \\
\hline & $\begin{array}{l}\text { Polystyrene } \\
\text { Foam }\end{array}$ & -.163 & .023 & \\
\hline \multirow{2}{*}{ 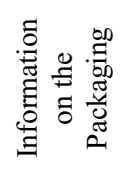 } & $\begin{array}{l}\text { Detail } \\
\text { Information }\end{array}$ & .184 & .017 & \multirow{2}{*}{17.772} \\
\hline & $\begin{array}{l}\text { Non Detail } \\
\text { Information }\end{array}$ & -.184 & .017 & \\
\hline \multirow{2}{*}{ 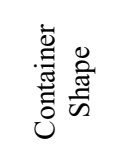 } & $\begin{array}{l}\text { With } \\
\text { Compartment }\end{array}$ & .123 & .017 & \multirow{2}{*}{15.356} \\
\hline & $\begin{array}{l}\text { Without } \\
\text { Compartment }\end{array}$ & -.123 & .017 & \\
\hline \multirow{2}{*}{ 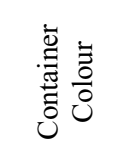 } & $\begin{array}{l}\text { Light (White, } \\
\text { Beige, etc) }\end{array}$ & .193 & .017 & \multirow{2}{*}{22.333} \\
\hline & $\begin{array}{l}\text { Dark (Black, } \\
\text { Brown, etc) }\end{array}$ & -.193 & .017 & \\
\hline
\end{tabular}

Individual utility value varies but when viewed as aggregate, utility value that has the highest positive value in sequence are packaging material, container colour, information on the packaging, and the container shape.

Conjoint analysis result indicate that packaging material are the most attribute that affect consumers' preferences of take-out food packaging, as for the other attributes have important values that are not too different.

Packaging material as the main attribute, has a highest utility value for packaging material base paper. Consumer choose light colour for container, indicate that consumers' perceived safe and comfort with light colour that can reflect the quality of food they consume. This is related to the main function of take-out food packaging to protect the product during distribution, and not as a marketing tools (Boyce et al, 2008).

Detail information on take-out food packaging prefer by consumers indicate that consumers concern about food safety, healthy, and environment. This attribute give added value for the packaging design.

Container shape with compartment have positive utility value that related with previous research that consumers prioritize convenience, include easy to consume the food they buy (Silayoi and Speece, 2007; Boyce et al, 2008; Binkley et al, 2008).

Conjoint Analysis calculation with aditif model are appropriate with assumption that has described before, so it can state that the research are valid internally. The respondents used that are representative to the population and the high accuracy in predicting the ranking show that the research are valid externally.

\subsection{Step 2: Cluster Analysis}

This research conduct Clustering to 263 respondents based on importance values from each respondent. Two stage clustering procedure using Ward's and K-Means to develop market segmentation.

Cluster analysis which using Ward's method have resulted agglomeration schedule table and dendrogram. Agglomeration schedule table used to consider how many cluster to define. By the table, it can be seen that from 1 to 259 point, there is no significance change, but a surge dramatically at the point 260,261 , and 262 .

Figure 4. Coefficient Graphic from Agglomeration Schedule Table

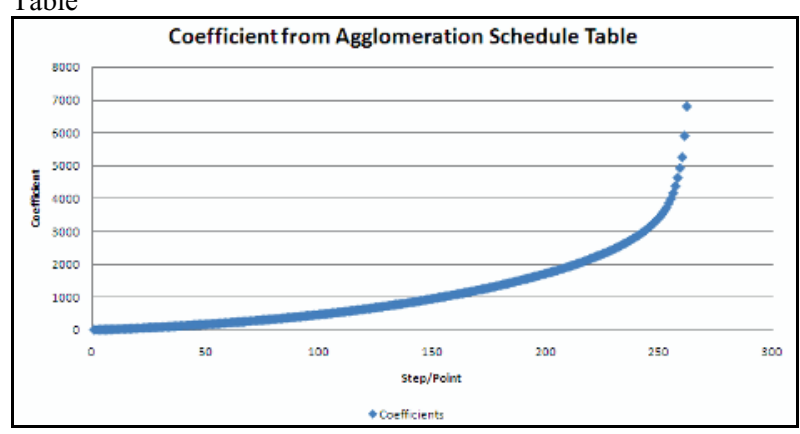

Coefficient value algorithm from 263 respondents generate the elbow to the graphic. By this result, the number of clustering group can be calculated by deduct the amount of respondents with the drastic surge on the coefficient value, that is $(263-260)=3$ clustering group.

The second stage is using K-Means method to improve Ward's method and show the selection of respondents by the clustering group.

In this research, one-way ANOVA used to test if there is a significance difference between the take-out food packaging attribute-level combination. F-test in one-way ANOVA for each clustering group show generally that there is significance differences between the clustering group, with $\mathrm{p}$-value $<0.01$, as can be seen in Table 3 . 

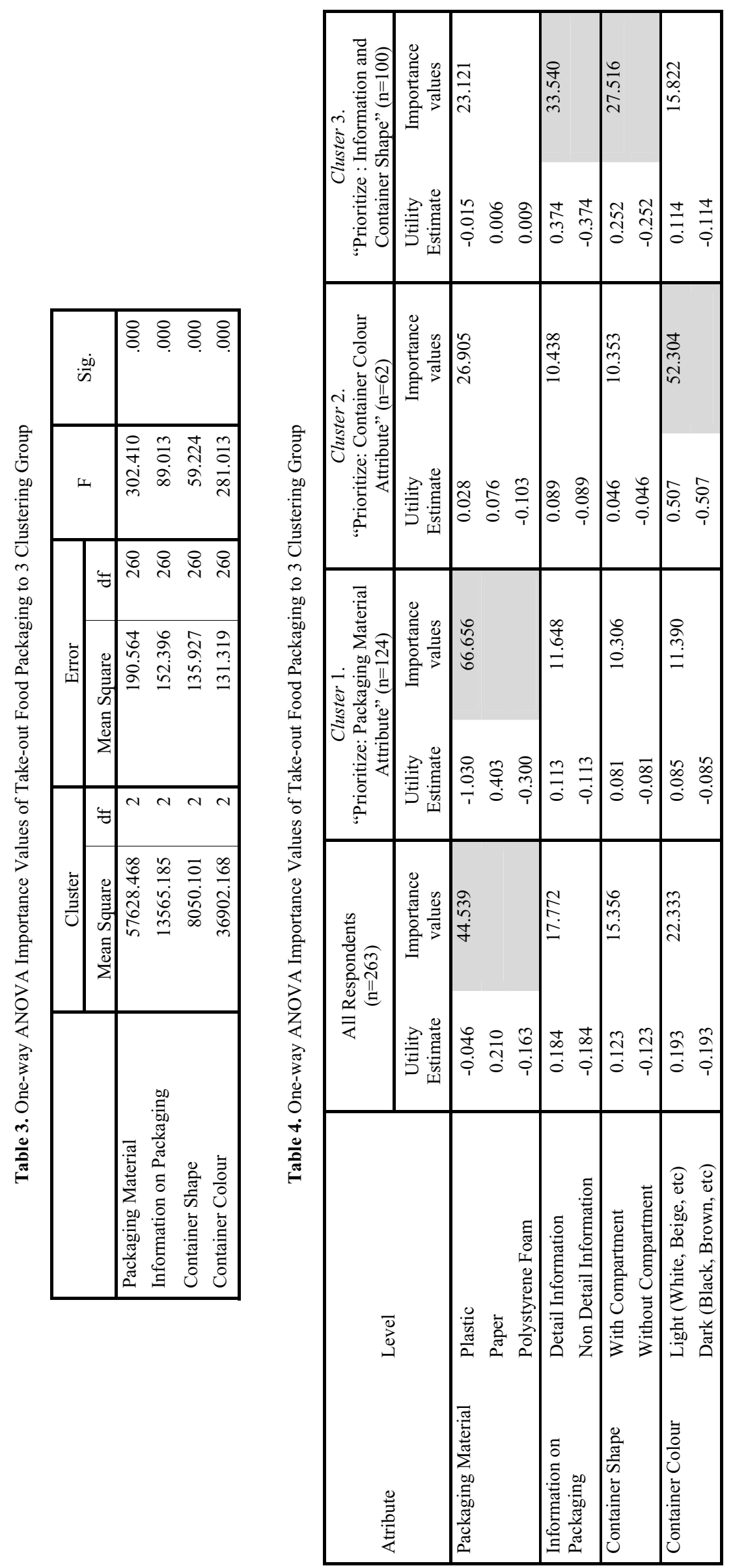


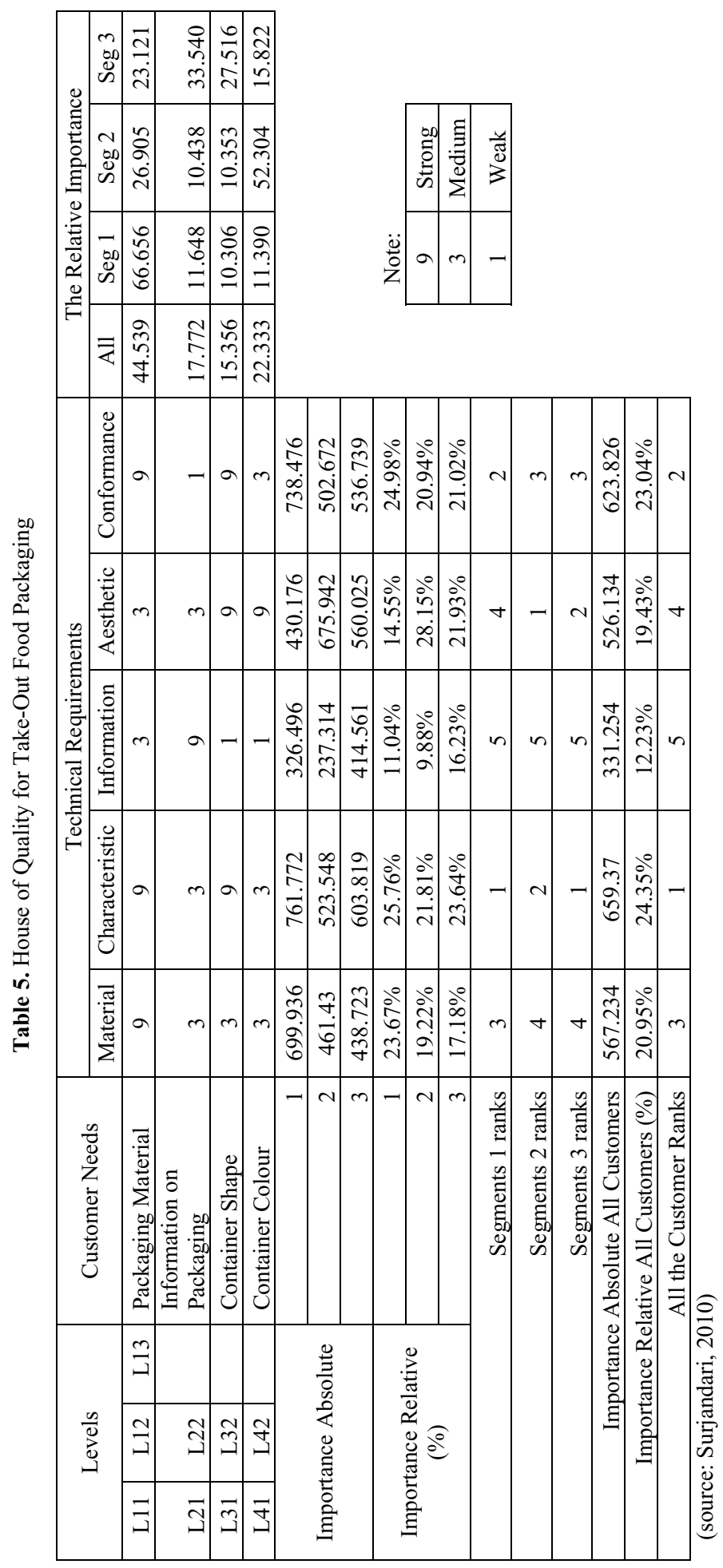




\subsection{Step 3: Conjoint Analysis for Each Segment}

In this step, conjoint analysis conducted to each cluster. The result of this conjoint analysis can be seen in Table 4 .

\subsection{Step 4: The HOQ Mechanism}

The first step to develop QFD are identify customer requirement, and this information has gained from the $1^{\text {st }}$ survey and FGD, that define packaging material, information on packaging, container shape, and container colour as main attributes.

Prioritizing product attributes based on customer requirement interpret from conjoint analysis result, in aggregate and each clustering group. The importance value in percentage form and in ranking can be seen in Table 6 .

Table 6. Relative Importance for Each Market Segment

\begin{tabular}{|l|c|c|c|c|c|c|c|c|}
\hline \multirow{2}{*}{ Attribute } & \multicolumn{4}{|c|}{ Relative Importance (\%) } & \multicolumn{4}{c|}{ Ranking } \\
\cline { 2 - 10 } & $\mathrm{A}$ & 1 & 2 & 3 & $\mathrm{~A}$ & 1 & 2 & 3 \\
\hline Packaging & 44, & 66, & 26, & 23, & 1 & 1 & 2 & 3 \\
Material & 539 & 656 & 05 & 121 & & & & 3 \\
\hline $\begin{array}{l}\text { Information } \\
\text { on }\end{array}$ & 17, & 11, & 10,4 & 33, & & & & \\
Packaging & 772 & 648 & 38 & 540 & 3 & 2 & 3 & 1 \\
\hline $\begin{array}{l}\text { Container } \\
\text { Shape }\end{array}$ & 15, & 10, & 10,3 & 27, & 4 & 4 & 4 & 2 \\
\hline $\begin{array}{l}\text { Container } \\
\text { Colour }\end{array}$ & 356 & 306 & 53 & 516 & & & & \\
\hline
\end{tabular}

Technical response has defined as alternative program that company can take to response customer requirements, as can be seen below:

1. Material Design Process

2. Characteristic Design Process

3. Information Design Process

4. Aesthetic Design Process

5. Quality Conformance Process

After defining the technical response, then the relationship matrix define to show the relationship between the technical response and customer requirement. This is the fundamental portion of HOQ. Each cell represents how an engineering parameter relates to customer requirements. 9 represent strong relationship, 3 represent medium relationship, 1 represent weak relationship, and we can leave the cell blank if there is no relationship at all.

Based on the relationship matrix and the relative importance value, we can conduct rank ordering, to assign the requirement with the highest priority and then decrease as the requirements have lower priority. We can determine rank ordering by calculating the relative importance based on customers' requirement and the relation matrix. The calculation is to get Importance Absolute, Importance Relative (\%), Importance Absolute All Customers, and Importance Relative All Customers $(\%)$, as can be seen in Table 5 .

\subsection{Step 5: The Analysis of The Results}

Physical characteristics of the design process of take-out food packaging is seen as the most important requirements, followed by conformance to quality, material packaging design, aesthetic design, and information design.

The first three requirements in line with the fulfilment of the functions value of take-out food packaging. The aesthetic and information design also important to give added-value that can perceived by customers and provide opportunity to improve customer satisfaction.

The rank order for each segment are not significantly difference compare to the rank order that based on all consumers. Companies can make policy based on the results of the development of House of Quality, and the policy should consider the ability of the company in product development process (Surjandari, 2010).

\section{Conclusion}

From the analysis that has been done, it can be concluded as follows. Packaging characteristics considered important by respondents, either with words that expressed directly by respondents, and the results of the assessment given by the respondents, represent that packaging material attributes have the highest importance values, followed by container colour, information on packaging, and container shape.

Consumer choice to the level of the attributes shown on the utility generates the value that consumers most liked packaging made of paper material, with a light colour packaging (white or beige), detail information, and the form of packaging which has compartment.

Segmentation is performed based on importance values respondents data, resulting in three clusters, that is cluster which prioritizes the attributes of packaging materials, cluster which prioritizes the container colour attribute, and the cluster that promotes information and forms of packaging. Each cluster has their own preference for the level-attribute combination. As for example, the cluster which prioritizes the attributes of packaging materials prefer the take-out food packaging with paper material, with a light colour packaging (white or beige), detail information, and the form of packaging which has compartment (it is the same level-attribute combination for all consumers).

The results of House of Quality development conform to what Surjandari (2010) has described that Conjoint Analysis - QFD is a useful combination of the two methodologies in product development, market segmentation, and the trade off between customers' requirements in the early stages of the HOQ process. Output of the HOQ process creates an opportunity for companies to develop products that conform to market requirements. For extent, company can develop difference product for difference market segmentation, as alternative policy, but must consider company ability. 


\section{References}

[1] Binkley, M, et al (2008), "Consumer Perception of Take out Food: Safe Handling Practices and Desired Package Attributes"

[2] Binkley, M., and Ghiselli, R. (2005), "Food safety issues and training methods for ready-to-eat foods in the grocery industry", Journal of Environmental Health, Vol. 68 No. 3, pp. 27-31.

[3] Boyce, Janice, Broz, Charles C., and Binkley, Margaret (2008), "Consumer Perspectives: Take out Packaging and Food Safety", British Food Journal, Volume 110 No. 8, pp. 819-828

[4] Goyal, Anita, and Singh, N.P., (2007), "Consumer Perception About Fast Food In India: An Exploratory Study", British Food Journal, Vol. 109 No. 2, pp. 182-195

[5] Hair Jr., Joseph F., et al., Multivariate Data Analysis, Prentice-Hall, 2006, sixth edition

[6] Silayoi, Pinya, and Speece, Mark (2007), "The Importance of Packaging Attributes: A Conjoint Analysis Approach", European Journal of Marketing, Volume 41 No. 11/12, pp. 1495-1517

[7] Silayoi, Pinya, and Speece, Mark (2004), "Packaging and purchase decision: An exploratory study on the impact of involvement level and time pressure", British Food Journal, Volume 106 No. 8 pp. 607-628

[8] Surjandari, Isti, Conjoint Analysis: Konsep dan Aplikasi, Penerbit Universitas Trisakti 